\title{
A RESEARCH ON THE DETECTION OF FAKE BUTTER BY TRADITIONAL AND MODERN METHODS
}

\section{Jale NAKTIYOK¹, Tuba Hatice DOĞAN²*}

${ }^{1}$ Atatürk University, Department of Chemical Engineering, 25240, Erzurum, Turkey

2 Atatürk University, Department of Chemical Engineering, 25240, Erzurum, Turkey

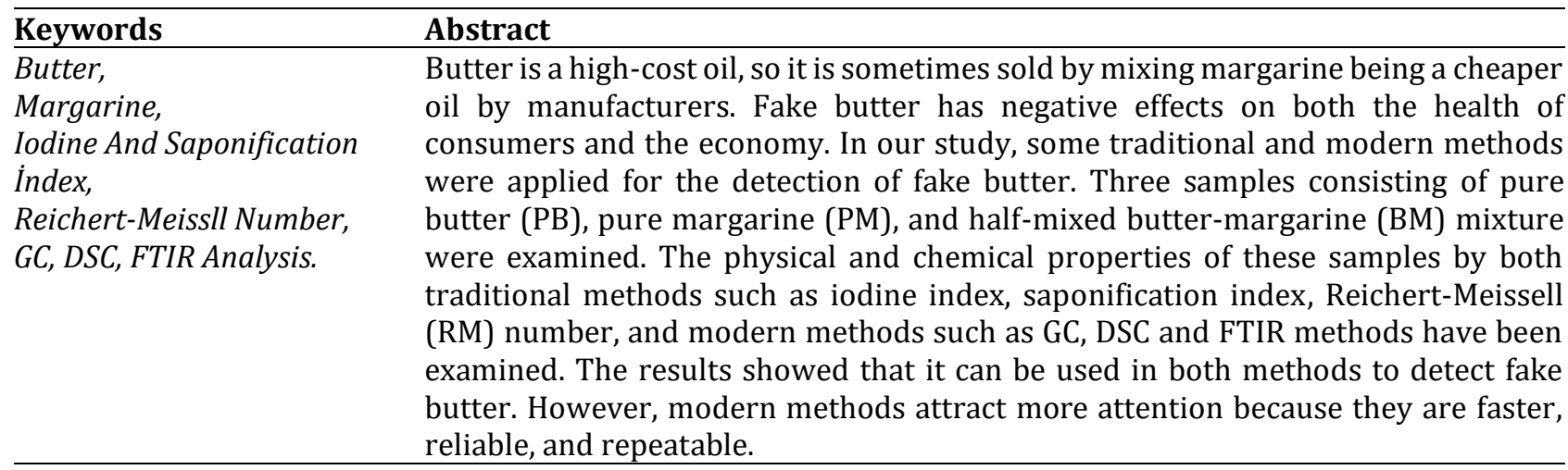

\section{SAHTE TEREYAĞININ GELENEKSEL VE MODERN YÖNTEMLERLE SAPTANMASI ÜZERİNE BİR ARAŞTIRMA}

\begin{tabular}{l}
\hline Anahtar Kalimeler \\
\hline Tereyağı, \\
Margarin, \\
Iyot Ve Sabunlaşma Indeksi, \\
Reichert-Meissll Sayısl, \\
GC, DSC, FTIR Analizleri.
\end{tabular}

\begin{abstract}
Öz
Tereyağı yüksek maliyetli bir yağ olduğu için, bazen üreticiler tarafından daha ucuz bir yağ olan margarin ile karıștırılarak satılmaktadır. Sahte tereyağı, hem tüketicilerin sağlığı hem de ekonomi üzerinde olumsuz etkilere sahiptir. Çalışmamızda sahte tereyağının tespiti için bazı geleneksel ve modern yöntemler uygulanmıștır. Saf tereyağı (ST), saf margarin (SM) ve yarı yarıya karıștırılmıș tereyağı-margarin (TM) karışımından oluşan üç numune incelenmiştir. Bu numunelerin fiziksel ve kimyasal özellikleri, iyot indeksi, sabunlaşma indeksi, Reichert-Meissell (RM) sayısı gibi hem geleneksel yöntemlerle hem de GC, DSC ve FTIR gibi modern yöntemlerle incelenmiștir. Sonuçlar, sahte tereyağını tespit etmek için her iki yönteminde kullanılabileceğini göstermiștir. Bununla birlikte, modern yöntemler, daha hızlı, güvenilir ve tekrarlanabilir oldukları için daha fazla ilgi çekmektedir.
\end{abstract}

Alıntı / Cite

Naktiyok, J., Doğan, TH., (2021). A Research on the Detection of Fake Butter by Traditional and Modern Methods, Journal of Engineering Sciences and Design, 9(2), 453-462.

\begin{tabular}{l|l}
\hline Yazar Kimliği / Author ID (ORCID Number) & Makale Süreci / Article Process
\end{tabular}

J. Naktiyok, 0000-0002-6316-4112

T.H. Doğan, 0000-0001-8369-9416

\begin{tabular}{|l|l|} 
Başvuru Tarihi / Submission Date & 04.09 .2020 \\
Revizyon Tarihi / Revision Date & 23.03 .2021 \\
Kabul Tarihi / Accepted Date & 05.04 .2021 \\
Yayım Tarihi / Published Date & 20.06 .2021 \\
\hline
\end{tabular}

\section{Introduction}

Dairy oils form the raw material of butter, which is a form of animal fat. Dairy oils contain vital fatty acids and fatsoluble vitamins. They are easily digestible and can melt at body temperature. All these properties of milk fats also

\footnotetext{
* ilgili yazar / Corresponding author: hatice@atauni.edu.tr, +90-537-655-2394
} 
increase the nutritional value of butter, which contains a high content of milk fat (about 82\%) (Gosewade et al., 2017). In addition to the high amount of milk fat and water in its composition, butter also contains phospholipids, hydrocarbons, sterols and sterol esters, complex glyceride oils, free fatty acids, fat-soluble vitamins, and minerals (Kumar et al., 2016). Butter, which has a superior aroma and taste, is a high-calorie dairy product. It is a concentrated source of milk fat and is produced by the churning of milk or cream (Hamed et al., 2019).

Dairy oils are the most economically valuable dairy product. However, using only milk fats as raw materials during the production of butter causes the cost of the oil to be high. Therefore, in order to reduce the high cost of butter, manufacturers sometimes attempt fraudulent works, such as mixing butter with cheaper animal or vegetable oils. In particular, margarine, which has a butter-like composition, is quite common to use for producing fake butter (ROTAR, 2017). Margarine is a food product produced by hydrogenation of vegetable oils and it contains minimum $80 \%$ oil in its composition. It also contains emulsifiers, vitamins, flavors, and preservatives (Wiedermann, 1978).

It is very important to detect fraudulent products in butter. Because fake butter can have negative effects on human health, dairy industry, and economy. Since margarine has similar properties with butter in terms of color, smell, and flavor, it is very difficult to detect fraudulent butter only with sensory tests (Altun \& Paksoy). Therefore, it has been used in modern methods such as GC, ATR-MIR spectroscopy, DSC and FTIR as well as traditional methods such as RM, iodine, saponification and Polenske numbers (Fatouh et al., 2005; Koca et al., 2010; REXHEPI et al.; TAHMAS KAHYAOĞLU \& ÇAKMAKÇI, 2016; Tan \& Che Man, 2000; Tan \& Man, 2002; Yoshinaga et al., 2013).

Reichert-Meissell (RM), iodine and saponification numbers are important chemical characteristics used in identifying the types of oils/fats and controlling their purity. The Reichert-Meissell (RM) number is a simple, fast, and inexpensive method. It shows the amount of low molecular weight fatty acids (butyric C4: 0, caproic C6: 0, caprylic C8: 0 and a small amount of capric C10: 0 acids) that are characteristic of milk fats (Deelstra et al., 2014). The RM number in the range of 17-35 indicates that the butter is pure (Metin, 2001).

The iodine number is a parameter that gives information about the degree of saturation and unsaturation of the oil. It shows the amount of iodine that $100 \mathrm{~g}$ oil can bind. The number of double bonds in the oil can be determined by using the iodine number (ROTAR, 2017). The iodine number is expected to be in the range of 20.4-34.6 for pure butter (Murthy \& Bhat, 1976).

Saponification number is the amount of $\mathrm{KOH}$ (as $\mathrm{mg}$ ) required for soaping of $1 \mathrm{~g}$ oil. It is widely used in determining the purity of oils/fats and fatty acids. The average molecular weight of oil can be found using the saponification number (ROTAR, 2017). The saponification number in the range of 210-233 indicates that the butter is pure (Hamed et al., 2019).

Quantitative analysis of the fatty acids in the oil is carried out in the analyzes made for the detection of fake butter using gas chromatography (GC). Butyric acid is especially characteristic of pure butter. In addition to butyric acid, the purity of butter is evaluated by considering the presence and amount of some other fatty acids that butter should contain (Molkentin, 2007).

The water and fatty acid compositions of butter and margarine, can be easily analyzed and compared by using the Differential Scanning Calorimeter (DSC). The proportions of these components affect the thermal properties of the final product. The DSC technique is an ideal tool for this type of research. In short, DSC analysis is used for quality control in production and research (Tan \& Che Man, 2000; Tan \& Man, 2002; Tomaszewska-Gras, 2013).

Differential scanning calorimeter (DSC) is a highly used thermo-analytical method to study edible oils and to determine the melting/crystallization properties of the fats. DSC is a sensitive, fast, and reproducible method. By comparing the DSC curves of both pure and mixed forms of edible oils, information about them can be obtained. The DSC method displays high accuracy, precision, and stability in food and drug analysis (Tomaszewska-Gras, 2013).

Fats do not have a specific melting temperature. However, they have melting temperature intervals. A dynamic method must be used to determine this temperature range. Thus, more than one endothermic peak will be obtained and the melting temperature range will be seen. These changes can be analyzed by DSC analysis. The DSC method has proven to be very useful for studying the melting behavior of fats (Tan \& Che Man, 2000; Tan \& Man, 2002).

FTIR spectroscopy is applied for qualitative analysis and characterization of fat, protein, and carbohydrates belonging to different food samples. In particular, FTIR analysis combined with some techniques is widely used to 
distinguish butter from other edible oils and it determine the acidity, fat, moisture of butter for quality control (Nurrulhidayah et al., 2013).

In this study, research has been made on traditional methods such as saponification number, iodine number, and Reichert-Meissl value and modern methods such as GC, DSC, and FTIR, which are used for the detection of fake butter mixed with margarine.

\section{Materials and Method}

\subsection{Materials}

The butter (cow milk) and margarine used in the study were obtained from a local market in Erzurum. While preparing the butter margarine mixture, samples of the same weight were taken from both pure butter (PB), and pure margarine (PM), and their homogeneous mixture (BM). All experiments were repeated for three times.

\subsection{Analysis}

\subsubsection{Analysis of $R-M$, iodine, and saponification numbers and some physicochemical properties of fat samples}

Three samples consisting of pure butter (PB), pure margarine (PM), and half-mixed butter-margarine (BM) mixture were analyzed. Reichert-Meissell (R-M) number of fat samples, TS 1331, iodine number, TS EN ISO 3961, and saponification number were determined according to TS EN ISO 3657 standards.

Some physicochemical properties such as fat amount (TS 1331), salt amount (TS 1333 IS01738), fat-free dry matter amount (TS 1331), moisture amount (TS 1331), acid number (TS EN ISO 660), and free fatty acids (TS EN ISO 660) of PB, PM, BM samples were also determined.

\subsubsection{Determination of Fatty Acid Composition}

Fat samples were first converted into fatty acid methyl esters (EN ISO 5509). Fatty acid compositions of samples were analyzed by gas chromatograpy system equipped with an auto-injector (SHIMADZU, QP 2010) and the RESTEK Rtx-Wax capillary column $(60 \mathrm{~m} \times 0.25 \mathrm{~mm}$ id., 0.25$)$. The initial oven temperature was $140{ }^{\circ} \mathrm{C}$ for 5 minutes, and it was increased to $240^{\circ} \mathrm{C}$ with heating rate of $3^{\circ} \mathrm{C} /$ minute, then it was maintained constant for 17 minutes.

\subsubsection{DSC analysis}

Approximately $10 \mathrm{mg}$ of each fat sample (with an accuracy of $0.01 \mathrm{mg}$ ) was placed in the pan made of $\mathrm{Al}_{2} \mathrm{O}_{3}$. DSC analysis was performed on the DSC 8500 Perkin Elmer $\left(-65^{\circ} \mathrm{C}-600^{\circ} \mathrm{C}\right)$ instrument. Firstly, samples were heated at a heating rate of $10^{\circ} \mathrm{C} / \mathrm{min}$ from $-65^{\circ} \mathrm{C}$ to $200^{\circ} \mathrm{C}$ and then they were cooled from $200^{\circ} \mathrm{C}$ to $-65^{\circ} \mathrm{C}$ at the same heating rate.

\subsubsection{FTIR analysis}

The structures of samples are characterized by Fourier Transform Infrared (FT-IR) spectroscopy. Spectra were obtained with Bruker VERTEX 70v instrument in the range of 4000-400 $\mathrm{cm}^{-1}$.

\section{Results and Discussion}

\subsection{Reichert-Meissel (R-M), saponification and iodine numbers}

Reichert-Meissl, iodine, saponification numbers, and some physicochemical properties of fat samples consisting of PB, PM, and BM mixture were analyzed. The results obtained are given in Table 1.

When Table 1 is examined, it is seen that the RM value of pure butter is 25.1. This value is in the range of 17-35 stated in the literature (Metin, 2001). The RM value of pure margarine was found to be 1.65 . This value also matches the max.7 value specified in the literature (Kurt et al., 2007). The RM value obtained for $50 \%$ butter + $50 \%$ margarine mixture was found to be 14.3. This value is not in the range specified in the literature for pure butter. This proves that the determined fat is not pure butter and it is mixed with margarine. In addition, the RM value (14.3) obtained for 50\% butter and 50\% margarine mixture was almost half of the RM values obtained for pure butter and pure margarine. However, while this value shows us that the butter is not pure, it does not give 
exact information about the ratio of the mixture. The RM values (Table 1) of the analyzed fats are consistent with the results obtained in many studies in the literature. Also, they show that RM is a very safe analysis that can be used for the detection of fake butter (Çakmakçı \& Kahyaoğlu, 2018; TAHMAS KAHYAOĞLU \& ÇAKMAKÇI, 2016).

Table 1. Reichert-Meissl, iodine, and saponification numbers and some properties of fat samples

\begin{tabular}{|c|c|c|c|}
\hline & PB & $\mathbf{P M}$ & BM \\
\hline Reichert Meissl (RM) & 25.1 & 1.65 & 14.3 \\
\hline Iodine number & 26.65 & 53.45 & 35.21 \\
\hline Saponification number & 217.3 & 197.9 & 205.9 \\
\hline \multicolumn{4}{|c|}{ Some physicochemical properties of fat samples } \\
\hline & PB & $\mathbf{P M}$ & BM \\
\hline Fat amount (\%) & 84 & 72 & 78 \\
\hline Salt amount (\%) & 0.035 & 0.19 & 0.13 \\
\hline Fat-free dry matter amount (\%) & 2 & 1.5 & 1.5 \\
\hline Moisture amount (\%) & 14 & 26.5 & 20.5 \\
\hline Acid number (mgKOH/g) & 1.10 & 0.84 & 1.01 \\
\hline Free fatty acids (as oleic acid, \%) & 0.55 & 0.42 & 0.5 \\
\hline
\end{tabular}

In addition, to RM number, the number of saponification of PB was found to be 217.3 (Table 1). This value is in the range of 210-233 given for the saponification number of milk fat (Hamed et al., 2019). As seen in Table 1, while the smallest saponification number belongs to PM (197.9), the saponification number of the BM mixture (205.9) is larger than PM but lower than that of PB. Since milk fats contain longer carbon chains and more saturated fatty acids, the saponification number of butter is higher than other oils (Çakmakçı \& Kahyaoğlu, 2018; Park et al., 2007). The decrease in the saponification number of the BM mixture may be related to the high molecular weight fatty acids of margarine mixed with butter. When Table 1 is examined, it is seen that the highest iodine number belongs to PM $(53,45)$, while the lowest iodine number belongs to PB $(26,65)$. A high iodine number means the presence of a high amount of unsaturated fatty acids (especially oleic and linoleic acids) in the oil (Hamed et al., 2019). Iodine number of milk fats is in the range of 20.4-34.6 (Murthy \& Bhat, 1976). The increase in the iodine number compared to the PB of the BM mixture confirms that it is the mixture.

\subsection{Determination of fatty acid composition with the help of Gas Chromatography (GC)}

Milk fats contain more than 400 fatty acids (Jensen, 2002). Table 2 shows the fatty acid profile (the list of major compounds) of fat samples.

When Table 2 is examined, it is seen that the fat sample with the highest saturated fatty acids ratio $(69,68)$ is PB and the fat sample with the highest unsaturated fatty acid ratio (45) is PM. This is an expected situation (Hamed et al., 2019). While the most saturated fatty acid in all fat samples is Palmitic acid, the most unsaturated fatty acids are oleic and elaidic acids. In addition, it is observed that buturic (C4: 0), caproic (C6: 0), and caprylic (C8: 0) acids (Deelstra et al., 2014), which are found only in milk fats, are absent in PM, and the amount in PB (6.91\%) is higher than the BM mixture (3.95\%) (Table 2). This helps us to detect butter.

Buturic acid (C4: 0) is one of the good indicators used in the detection of fake butter in fat samples using GC-FID, as it is found in milk fats obtained from only cows and other mammals (Molkentin \& Precht, 1998; Yoshinaga et al., 2013). The fact that the value of C4: 0 is 2.72 for PB, while it is zero for PM (Table 2) supports this situation. The C4: 0 value for the BM mixture was found to be 1.37 . This value corresponds to almost half of the 2.72 value found for PB. Thus, it gives us some clues about the mixing ratio of butter. 
Table 2. Fatty acid composition of fat samples (\% weight)

\begin{tabular}{|c|c|c|c|c|c|}
\hline & Fatty acids & Carbon number & PB & PM & BM \\
\hline & Butyric & $\mathrm{C} 4: 0$ & 2.72 & $*$ & 1.37 \\
\hline & Caproic & $\mathrm{C} 6: 0$ & 1.78 & $*$ & 1.01 \\
\hline & Caprylic & $\mathrm{C} 8: 0$ & 2.41 & $*$ & 1.57 \\
\hline \multirow[t]{5}{*}{ Saturated fatty acids } & Lauric & C12:0 & 2.92 & 5.86 & 4.55 \\
\hline & Myristic & C14:0 & 11.08 & 2.49 & 7.00 \\
\hline & Pentadecanoic & C15:0 & 1.24 & $*$ & $*$ \\
\hline & Palmitic & C16:0 & 35.12 & 35.97 & 35.92 \\
\hline & Stearic & C18:0 & 12.41 & 8.87 & 9.23 \\
\hline \multirow[t]{2}{*}{ Total } & & & 69.68 & 53.19 & 60.65 \\
\hline & Palmitoleic & C16:1 & 1.57 & $*$ & $*$ \\
\hline \multirow[t]{2}{*}{ Unsaturated fatty acids } & Oleic + Elaidic & $\mathrm{C} 18: 1 \mathrm{n} 9 \mathrm{c}+\mathrm{C} 18 \mathrm{~s} 1 \mathrm{n} 9 \mathrm{t}$ & 21.86 & 25.21 & 24.45 \\
\hline & Linoelaidic & $\mathrm{C} 18: 2 \mathrm{n} 6 \mathrm{t}$ & 3.22 & 19.79 & 11.58 \\
\hline Total & & & 26.65 & 45 & 36.03 \\
\hline
\end{tabular}

* undetectable or less than $1 \%$

\subsection{DSC analysis of samples}

For DSC analysis, samples were heated in the air environment from $-65^{\circ} \mathrm{C}$ to $200^{\circ} \mathrm{C}$ at heating rate of $10^{\circ} \mathrm{C} / \mathrm{min}$ and then cooled from $200^{\circ} \mathrm{C}$ to $-65^{\circ} \mathrm{C}$ at the same heating rate. DSC melting/crystallization cycles obtained for butter and margarine are shown in Figure 1.

When Figure 1A is examined, many melting peaks are seen. The temperature values of these points are indicated on the DSC profile. The endothermic peak seen at $1.6^{\circ} \mathrm{C}$ corresponds to the melting temperature of the water and it indicates that the water in the structure of the butter melt. Temperatures such as $9.6,16.2,32.54,54.9^{\circ} \mathrm{C}$ are melting peaks of the fatty acids in the structure. As stated in the literature, it is possible to obtain a large number of endothermic peaks in the melting profiles of fats (Tan \& Man, 2002). The most important reason for this is that it depends on the distribution of fatty acids, which are extremely important for their applications in the food industry. There is a significant relationship between melting curves and fatty acid contents. Highly saturated fatty acids melt at higher temperatures compared to unsaturated fatty acids. 

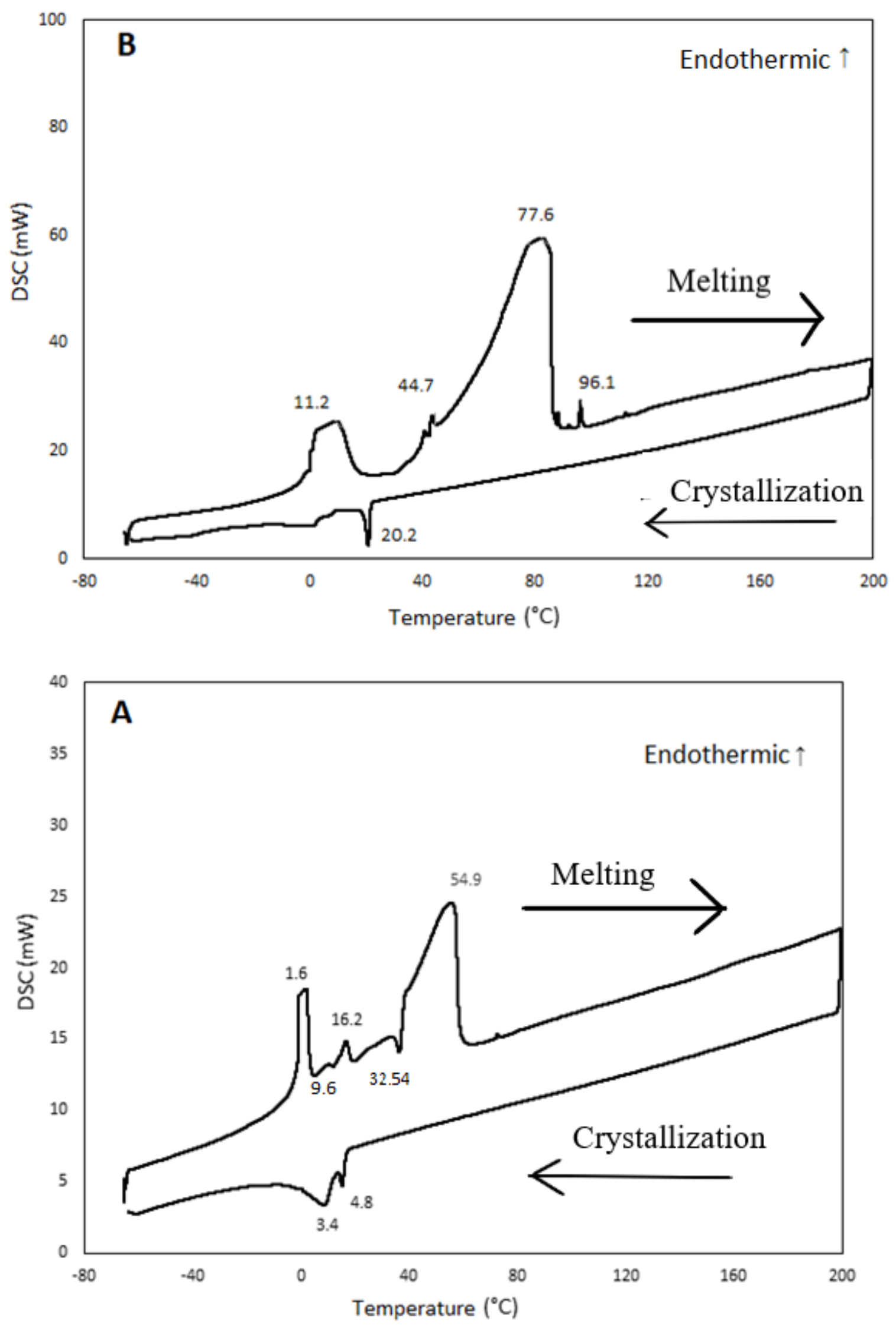

Figure 1. DSC cycle of melting/crystallization of butter (A) and margarine (B) at a heating rate of $10^{\circ} \mathrm{C} / \mathrm{min}$ 
In the heating program, a cycle was performed from $200^{\circ} \mathrm{C}$ to $-65^{\circ} \mathrm{C}$ with the heating rate of $10^{\circ} \mathrm{C} / \mathrm{min}$. Melting and crystallization curves were obtained in the cycle program. When the crystallization curve is examined, two crystallization peaks are seen. Butter melting up to $200^{\circ} \mathrm{C}$ now has a new polymorphic structure. Therefore, crystallization temperatures were obtained at different points $\left(3.4\right.$ and $\left.4.8^{\circ} \mathrm{C}\right)$.

When Figure 1B is examined, the melting and crystallization curves of margarine are seen. It is remarkable that the melting temperatures of the fatty acids of margarine shift towards higher temperatures and the melting peaks are wider than butter. The first endothermic peak of margarine is $11.2^{\circ} \mathrm{C}$ and it is quite wide. It is understood that a certain amount of fatty acids dissolves together with the water in the structure and they are less stable than other fatty acids. It can be concluded that the butter is softer in storage conditions such as refrigerator and at room temperature. Because the melting peak of water corresponding to approximately $1.6^{\circ} \mathrm{C}$ is narrower. Also, the area of this peak obtained in butter is lower according to in margarine. The crystallization temperature of margarine is $20.2^{\circ} \mathrm{C}$.

It is seen that the melting process in butter is completed at approximately $60^{\circ} \mathrm{C}$. However, this temperature has increased up to $97^{\circ} \mathrm{C}$ in margarine. This feature also indicates the presence of shorter chain fatty acids in butter compared to the margarine. In addition, the melting temperatures of the margarine shift to higher temperatures. Hence it can remain at room temperature without melting.

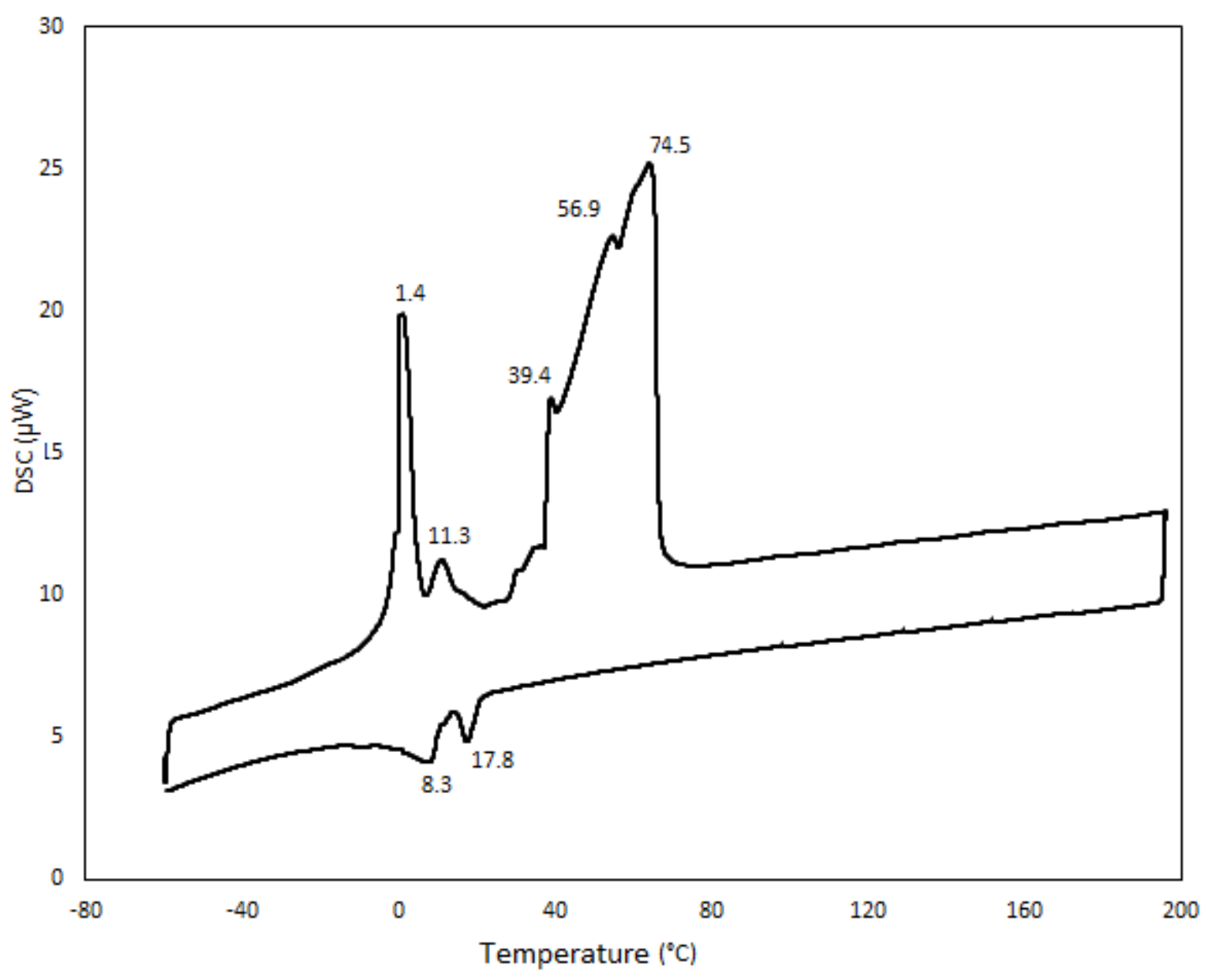

Figure 2. DSC cycle of melting/crystallization of $50 \%$ butter-margarine at a heating rate of $10^{\circ} \mathrm{C} / \mathrm{min}$

Figure 2 shows the DSC melting/crystallization cycle obtained at a heating rate of $10^{\circ} \mathrm{C} / \mathrm{min}$ for $50 \%$ butter $-50 \%$ margarine mixture. When the graphic is examined, it is seen that the melting peak of water coincides with the melting peak in butter. In Figure 1 (A-B), the highest melting peaks of butter and margarine can be easily seen in Figure 2. The mixture's DSC peaks have many melting peaks. These small peaks seen on the large melting peak of fatty acids also indicate that the sample mixture cannot be pure. The melting process of the mixture is completed at approximately $75^{\circ} \mathrm{C}$. The crystallization curve displays that while the crystallization temperature of the butter is relatively low value such as $3.4^{\circ} \mathrm{C}$ and $4.8^{\circ} \mathrm{C}$, the temperature of $50 \%$ butter-50\% margarine mixture increases to $8.3 \mathrm{oC}$ and $17.8 \mathrm{oC}$. In the literature, it has been obtained the same results (Aktaş \& Kaya, 2001). 


\section{4. FTIR analysis}

It was analyzed by FTIR spectroscopy to determine the structural properties of the samples (butter, margarine, and $50 \%$ butter-50\% margarine). The wavenumbers of the characteristic groups in the examples are given in Table 3.

Table 3. Major infrared bands and their characteristic functional groups (Nurrulhidayah et al., 2013)

\begin{tabular}{|c|c|}
\hline Wavenumber $\left(\mathrm{cm}^{-1}\right)$ & Assignment \\
\hline $3600-3000$ & O-H (water) stretching \\
\hline 3008 & $=\mathrm{C}-\mathrm{H}$ stretching (cis) (fat) \\
\hline 2920 & $-\mathrm{CH}\left(\mathrm{CH}_{2}\right)$ Asymmetric stretching (fat) \\
\hline 2850 & $-\mathrm{CH}\left(\mathrm{CH}_{2}\right)$ Symmetric stretching (fat) \\
\hline 1740 & $-\mathrm{C}=\mathrm{O}$ (ester), $\mathrm{COO}^{-}, \mathrm{COOH}$ stretching (fat) \\
\hline $1690-1640$ & $\mathrm{C}=\mathrm{N}$ stretching (protein) \\
\hline 1465 & $-\mathrm{C}-\mathrm{H}\left(\mathrm{CH}_{2}\right.$ ve $\left.\mathrm{CH}_{3}\right)$ (fat) \\
\hline 1377 & $-\mathrm{C}-\mathrm{H}\left(\mathrm{CH}_{3}\right)$ Symmetric stretching \\
\hline 1237 & Stretching vibration of $\mathrm{C}-\mathrm{O}$ ester groups (fat) \\
\hline 1170 & Stretching vibration of $-\mathrm{C}-\mathrm{O}$ ester groups (fat) \\
\hline 1097 & $-\mathrm{C}-\mathrm{O}$ stretching (fat) \\
\hline 967 & -HC=CH- stretching (trans groups, fat) \\
\hline 724 & $-\mathrm{HC}=\mathrm{CH}-$ (cis) stretching (fat) \\
\hline
\end{tabular}

FTIR spectra of the samples are shown in Figure 3. Examining the FTIR spectra, we can see that the 0-H band, especially in the range of $3600-3000 \mathrm{~cm}^{-1}$, is very wide and distinct in the margarine. It can be said from both DSC and FTIR analyses that the amount of water in margarine is quite high.

Margarine and butter are generally very different from each other because butter is animal origin, while margarine is vegetable fat mixed with water. Butter does not usually contain any additives, while margarine may contain different ingredients (antioxidants, vitamins, coloring agents, and emulsifiers).

The methylene groups of fats are in the range of 3000-2800 $\mathrm{cm}^{-1}$ in FTIR analysis. The stretching of the structures in this range is given in Table 3, in detail. Especially for butter, the intensity of spectra in this region is so much than those of margarine. In addition, the spectrum belonging to the $1740 \mathrm{~cm}^{-1}$ carbonyl $(-\mathrm{C}=0)$ region is again higher in butter. The $\mathrm{C}=\mathrm{N}$ vibration in the range of $1690-1640 \mathrm{~cm}^{-1}$ is higher in margarine than butter, it is even absent in butter. However, the stretching of $-\mathrm{HC}=\mathrm{CH}$ at $967 \mathrm{~cm}^{-1}$ is the signal spectrum used for the determination of trans-fatty acids in fats and oils (Leite et al., 2019; Nurrulhidayah et al., 2013). The results obtained are quite compatible with the literature (REXHEPI et al.). It is understood from Figure 3 that 50\% butter and 50\% margarine has average peak values of pure butter and pure margarine. 


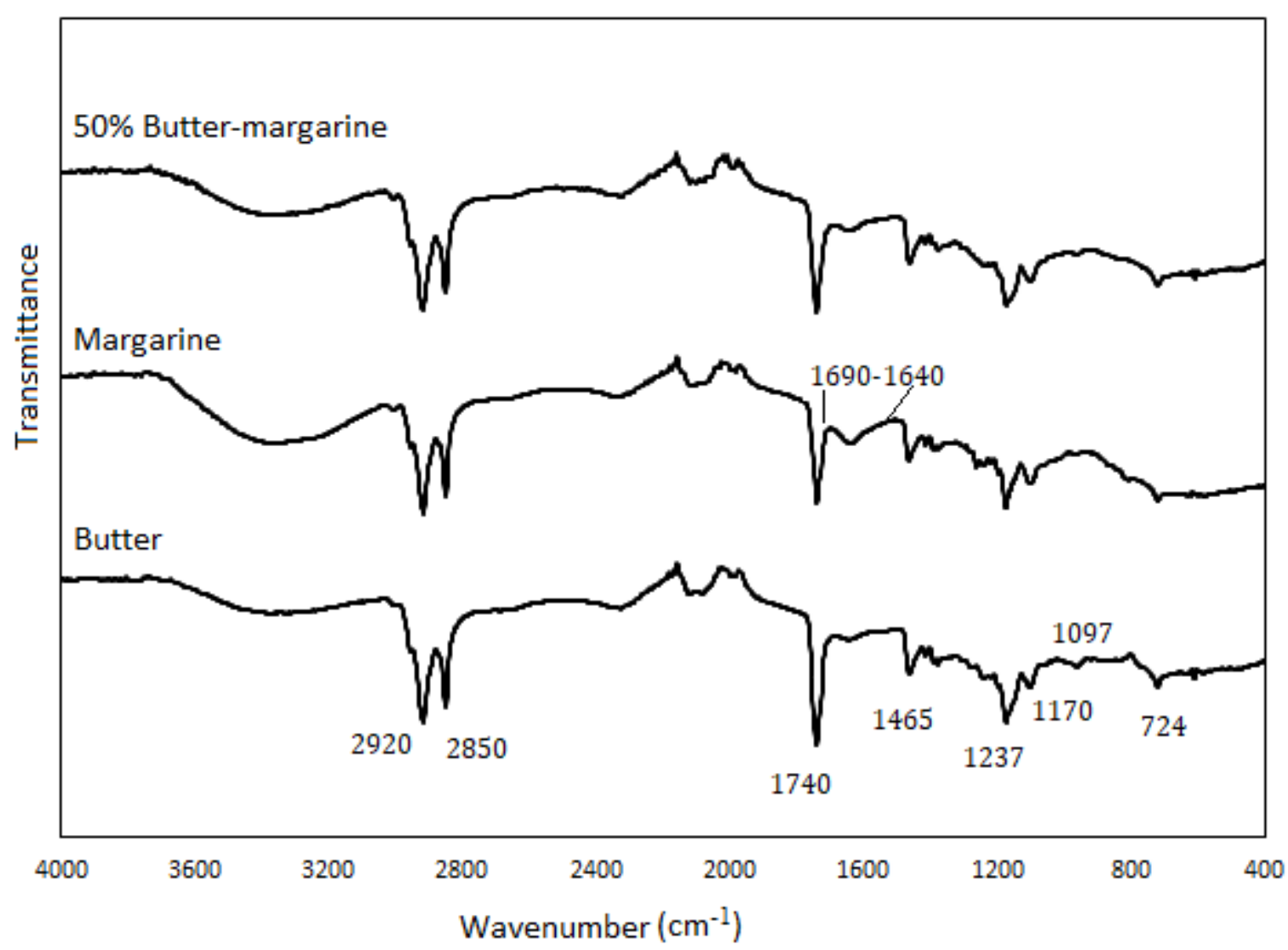

Figure 3. FTIR spectra of butter, margarine, and $50 \%$ butter and margarine mixture

According to these results, strong FTIR spectrum in butter are especially $1740 \mathrm{~cm}^{-1}$ peak, and in the range of 2900 $2800 \mathrm{~cm}^{-1}$ peak (Nurrulhidayah et al., 2013). The margarine has a pronounced $\mathrm{C}=\mathrm{N}$ stretching in the range of 1690$1640 \mathrm{~cm}^{-1}$, and a wide $0-\mathrm{H}$ stretching of 3600-3000 cm-1. In the literature, $1740 \mathrm{~cm}^{-1}$ (-C=0 Ester vibration) peak is the most dominant peak in the FTIR analysis of butyric acid, which is the most important indicator of butter (www.chemicalbook.com). These peaks give us clues in determining butter.

\section{Conclusions}

In our study, a detailed analysis of pure butter, pure margarine, and $50 \%$ butter-margarine mixture by some traditional (Reichert-Meissl, saponification and iodine numbers) and modern methods (GC, DSC, and FTIR) were performed. The results show that mixing margarine with butter ( $50 \%$ butter-margarine) decreases the numbers of R-M and saponification while it increases the number of iodine. It is seen that the GC method is a very reliable method for detecting fake butter. In DSC analysis, it was understood that butter has narrow melting peaks at very low temperatures, while margarine has wider melting peaks at higher temperatures. In the DSC curve of 50\% butter-margarine, it was determined that especially the number of melting peaks of fatty acids increased. According to DSC and FTIR analysis, it is remarkable that the amount of water in margarine is much higher than butter. Especially in FTIR analysis, some peaks $\left(1740 \mathrm{~cm}^{-1}\right.$ peak and the range of $\left.2900-2800 \mathrm{~cm}^{-1}\right)$ guide us in determining the purity of butter.

\section{Conflict of interest}

No conflict of interest was declared by the authors.

\section{References}

Aktaş, N., Kaya, M. 2001. Detection of beef body fat and margarine in butterfat by differential scanning calorimetry. Journal of Thermal Analysis and Calorimetry, 66(3), 795-801.

Altun, S.K., Paksoy, N. Evaluation of Reichert Meissl Values of Butter Produced in Turkey.

Çakmakçı, S., Kahyaoğlu, D.T. 2018. A Comparative Study On Some Properties And Oxidation Stability During Storage Of Butter Produced From Different Animals'milk. Glda, 43(2), 283-293. 
Deelstra, H., Burns, D.T., Walker, M. 2014. The adulteration of food, lessons from the past, with reference to butter, margarine and fraud. European Food Research and Technology, 239(5), 725-744.

Fatouh, A., Singh, R., Koehler, P., Mahran, G., Metwally, A. 2005. Physical, chemical and stability properties of buffalo butter oil fractions obtained by multi-step dry fractionation. Food chemistry, 89(2), 243-252.

Gosewade, S., Gandhi, K., Ranvir, S., Kumar, A., Lal, D. 2017. A study on the physico-chemical changes occurring in ghee (butter oil) during storage. Indian J Dairy Sci, 70(1), 81-88.

Hamed, A.M., Aborass, M., El-Kafrawy, I., Safwat, G. 2019. Comparative study for the detection of Egyptian buffalo butter adulteration with vegetable oils using conventional and advanced methods. Journal of Food Safety, 39(4), e12655.

Jensen, R.G. 2002. The composition of bovine milk lipids: January 1995 to December 2000. Journal of dairy science, 85(2), 295-350.

Koca, N., Kocaoglu-Vurma, N., Harper, W., Rodriguez-Saona, L. 2010. Application of temperature-controlled attenuated total reflectance-mid-infrared (ATR-MIR) spectroscopy for rapid estimation of butter adulteration. Food Chemistry, 121(3), 778-782.

Kumar, A., Goyal, S., Munesh, K.V., Kumar, L. 2016. Study on physico-chemical analysis of ghee. South Asian J. of Food Technol. and Environ, 2(3\&4), 448-451.

Kurt, A., Çakmakçı, S., Çağlar, A. 2007. Süt ve mamulleri muayene ve analiz metotları rehberi. Atatürk Üniv. Ziraat Fak. Yay(18).

Leite, A.I.N., Pereira, C.G., Andrade, J., Vicentini, N.M., Bell, M.J.V., Anjos, V. 2019. FTIR-ATR spectroscopy as a tool for the rapid detection of adulterations in butter cheeses. $L W T, 109,63-69$.

Metin, M. 2001. Süt Teknolojisi Sütün Bileşimi ve İşlenmesi. Bölüm, Genişletilmiş Üçüncü Baskl, Ege Üniv. Mühendislik Fak. Yay(33).

Molkentin, J. 2007. Detection of foreign fat in milk fat from different continents by triacylglycerol analysis. European Journal of Lipid Science and Technology, 109(5), 505-510.

Molkentin, J., Precht, D. 1998. Comparison of gas chromatographic methods for analysis of butyric acid in milk fat and fats containing milk fat. Zeitschrift für Lebensmitteluntersuchung und-Forschung A, 206(3), 213-216.

Murthy, M.R., Bhat, G. 1976. Iodine number determination of milk fat and vegetable fats by refractometry. Journal of the American Oil Chemists' Society, 53(9), 577-580.

Nurrulhidayah, A., Man, C.Y., Rohman, A., Amin, I., Shuhaimi, M., Khatib, A. 2013. Authentication analysis of butter from beef fat using Fourier Transform Infrared (FTIR) spectroscopy coupled with chemometrics. International Food Research Journal, 20(3), 1383.

Park, Y., Juárez, M., Ramos, M., Haenlein, G. 2007. Physico-chemical characteristics of goat and sheep milk. Small ruminant research, 68(1-2), 88-113.

REXHEPI, F., KURTI, G., FERATI, F., SHALA, S. FTIR-SPECTROSCOPY STUDY OF MICROWAVE AND CONVENTIONAL HEATING ON THE DEGRADATION OF MARGARINE AND BUTTER.

ROTAR, R. 2017. Study On Identifying Butter Faking By Substitution With Pork Fat Or With Margarine. Food and Environment Safety Journal, 9(1).

TAHMAS KAHYAOĞLU, D., ÇAKMAKÇI, S. 2016. Determination of the adulteration of butter with margarine by using fat constants.

Tan, C., Che Man, Y. 2000. Differential scanning calorimetric analysis of edible oils: comparison of thermal properties and chemical composition. Journal of the American Oil Chemists' Society, 77(2), 143-155.

Tan, C., Man, Y.C. 2002. Comparative differential scanning calorimetric analysis of vegetable oils: I. Effects of heating rate variation. Phytochemical Analysis: An International Journal of Plant Chemical and Biochemical Techniques, 13(3), 129-141.

Tomaszewska-Gras, J. 2013. Melting and crystallization DSC profiles of milk fat depending on selected factors. Journal of Thermal Analysis and Calorimetry, 113(1), 199-208.

Wiedermann, L.H. 1978. Margarine and margarine oil, formulation and control. Journal of the American Oil Chemists' Society, 55(11), 823-829.

Yoshinaga, K., Nagai, T., Mizobe, H., Kojima, K., Gotoh, N. 2013. Simple method for the quantification of milk fat content in foods by LC-APCI-MS/MS using 1,2-dipalmitoyl-3-butyroyl-glycerol as an indicator. Journal of oleo science, 62(3), 115-121. 